\title{
SEED SOURCE EFFECTS ON GERMINATION, GROWTH, AND YIELD OF CARROTS UNDER NATURAL FARMING
}

\author{
You KATSU ${ }^{1}$, Kotaro KATO ${ }^{2}$, Shuji $\mathrm{ABE}^{2}$, Kae MIYAZAWA ${ }^{1 *}$ \\ ${ }^{1}$ Department of Global Agricultural Sciences, Graduate School of Agricultural and Life Sciences, \\ the University of Tokyo, Tokyo, Japan \\ ${ }^{2}$ Institute for Agriculture, Medicine, and the Environment, Izunokuni, Japan
}

Received: December 2020; Accepted: June 2021

\begin{abstract}
Natural farming is a type of low-input sustainable agricultural system that is characterized by the avoidance of the use of any animal materials. Production of self-produced seeds by farmers is recommended under natural farming environments, with an expectation of improved crop growth and yield. However, there have been no scientific studies that investigated the performance of self-produced seeds under natural farming. This study investigated the germination rate, growth, and yield of carrots (Daucus carota L.) from different seed sources under natural farming. The main experimental factor was the cultivation method: CT - control; $\mathrm{CF}$ - conventional farming; NF1 - natural farming with tillage and compost input; and NF2 - natural farming without tillage and compost, and the subfactor was the seed source: OPN-open-pollinated seeds self-produced under natural farming; OPC - open-pollinated seeds produced under conventional farming; and $\mathrm{HB}$ - hybrid seeds. The germination rate of OPN seeds was higher than that of other seeds. In addition, root fresh weight and other root parameters of OPN were as high as for HB seeds. This suggests that using self-produced seeds by farmers improves crop performance in a natural farming system.
\end{abstract}

Key words: epigenetic variation, maternal environment effect, natural farming, no-tillage system, seed germination

\section{INTRODUCTION}

Natural farming ("Shizen-noho" or "Shizen-no" in Japanese) is a type of organic farming that is widely perceived in Japan to be a method of sustainable cultivation. Since the development of theories and methodologies in the 1930-1940s, natural farming has spread not only in Japan but also throughout the world (Fukuoka 2004; Sawanobori \& Komatsuzaki 2019). The most distinguishing feature of natural farming from organic farming is that it does not use any materials derived from animals, including manure (Sawanobori \& Komatsuzaki 2019). Some of the natural farming groups do not even till or weed to avoid disturbing the soil surface. These methods often result in lower yields; the amount of soil nutrients readily available to plants is generally lower than other farming methods, and weeds compete with crop growth. Despite the disadvantage of low yield, natural farming continues to attract many people (Kawaguchi et al. 2014; Mitra et al. 2017).
This is because natural farming is considered to be more compatible with nature and more sustainable than organic farming (Fukuda 2018).

Since no survey has been conducted on the current status of natural farming, it is not possible to provide figures on the area under natural farming cultivation or the number of natural farming practitioners. However, the following data provided by Japan's Ministry of Agriculture, Forestry, and Fisheries (MAFF 2017) may help in understanding the current state of agriculture in Japan. The number of agricultural management entities was approximately 1.38 million in 2015 , of which 1.34 million were family-owned entities, accounting for $98 \%$ of the total agricultural management entities. Of these agricultural management entities, $52.8 \%$ operate less than 1 ha and $91.2 \%$ less than 5 ha (Fukasawa 2020). The area of Japanese Agricultural Standard - JAS-certified organic farming - was only $0.5 \%$ of the total agricultural land in Japan in 2017 (Sawanobori \& Komatsuzaki 2019). 
Due to the high cost of obtaining JAS organic certification, in fact, the percentage of farmland without JAS certification has increased by about $19 \%$ from 2009 to 2017 (MAFF 2019), and the number of organic farmers without JAS certification is about double that of certified organic farmers (Sawanobori \& Komatsuzaki 2019).

For a long time, Japan relied on imports of chemical fertilizers, agricultural chemicals, and even organic fertilizers. These materials can be used at a low cost in the short term, but in the long run, there is a risk of increased costs, both economically and environmentally. Researching and practicing natural farming methods from a long-term perspective will be effective as one way to guarantee sustainable production of agricultural products in the future. In natural farming, many changes observed are longterm, occurring slowly over time (Takahashi 2010). Production of on-farm seeds adapting to a natural farming environment across generations has been positioned as one of the important technologies in natural farming (Sawanobori \& Komatsuzaki 2019). Phenotypic plasticity through epigenetic mechanisms may be an important contributor to the adaptation of plant species to different environments (Bräutigam et al. 2013; Balao et al. 2018). Studies have indicated that the ancestral environmental conditions of plants can influence the progeny phenotype through epigenetic mechanisms (Boyko \& Kovalchuk 2008). Therefore, producing self-produced seeds across generations may potentially promote seed germination, growth, and yield of vegetables under natural farming conditions.

Although hybrid seeds often have higher yields compared to open-pollinated seeds (Kutka 2011), they can perform well only under high-input agricultural management (Macharia et al. 2010; Omondi et al. 2014). Conversely, open-pollinated seeds can be produced by farmers. This means that self-produced seeds adapted to local soil conditions can potentially result in higher crop yields compared to hybrid seeds. However, to the best of the authors' knowledge, there have been no scientific studies that investigated and compared the performance of self-produced seeds under natural farming to other types of seeds. This paper reports the findings of a field experiment investigating the crop performance from different seed sources under natural farming conditions.
A root vegetable was selected because the root-to-shoot $(\mathrm{R}: \mathrm{S})$ ratio has been shown to be altered by the nutritional conditions of the maternal plant (Verhoeven \& van Gurp 2012). Open-pollinated seeds of carrots (Daucus carota L.) produced on the farm under natural farming were compared with seeds of the same cultivar produced under conventional farming and with seeds of a hybrid cultivar used commonly in conventional farming. The germination rate, growth, and yield of carrots from each type of seed were studied under four different cultivation methods, including two different natural farming methods.

\section{MATERIALS AND METHODS}

\section{Experimental site}

The field experiment took place at the Institute for Agriculture, Medicine, and the Environment, Izunokuni, Shizuoka, Japan $\left(139^{\circ} 1^{\prime} \mathrm{E}, 35^{\circ} 3^{\prime} \mathrm{N}\right)$ during the growing seasons of 2017 and 2018 . The field had been left fallow for 3 years before the experiment. The soil of the field was Light Colored Andosol (Tabuchi et al. 2008), and the soil properties of the experimental site at the beginning of the experiment are shown in Table 1. The daily temperature and precipitation values at the field site during the growing seasons are shown in Figure 1.

\section{Experimental design}

The experimental design was a split-plot, with cultivation methods assigned to the main plots and seed sources assigned to subplots. The experiment had three replications. The cultivation methods were: $\mathrm{CT}$ - control; CF - conventional farming; NF1 - natural farming with tillage and compost input; and NF2 natural farming without tillage and compost. The seed sources were OPN - open-pollinated seeds produced under natural farming; OPC - open-pollinated seeds produced by a seed company under conventional farming; and HB - hybrid seed produced under conventional farming and obtained from a seed company. The main plot measured $4 \mathrm{~m} \times 5 \mathrm{~m}$, within which three subplot ridges, $1 \mathrm{~m}$ wide and $3 \mathrm{~m}$ long, were formed.

CT plots were given tillage without any fertilization. The CF plots were tilled, and chemical fertilizer was applied (Table 2). The NF1 method was adapted from a method used by the Natural Farming Academy of the Mokichi Okada Association; it comprised tillage and application of plant material compost. Considering the mineralization rate of nitrogen 
(11\% of the total nitrogen applied), we applied grass compost with concentrations of $\mathrm{N}, \mathrm{P}_{2} \mathrm{O}_{5}$, and $\mathrm{K}_{2} \mathrm{O}$ of $2.50 \% \pm 0.70,2.82 \% \pm 0.14$, and $4.94 \% \pm 0.27$ (mean $\pm \mathrm{SD}$ ), respectively. The NF2 method was adapted from a method used by Akame Natural Farming School (Akame Shizennō Juku), Sakurai, Nara, Japan (Fukuda 2018); it was a no-tillage system, without application of compost, and weeds were cut at the soil surface and spread as mulch.

The open-pollinated seed cultivar for the 2017 autumn cultivation was 'Kuroda-gosun', but the cultivar for the 2018 spring and autumn cultivations was changed to 'Chikumano-gosun' due to the unavailability of seeds for 2018. Both OPN seeds were obtained from the same institute where the experiment was carried out. 'Kuroda-gosun' had been self-produced for more than 10 generations under natural farming conditions, and 'Chikumanogosun' had been self-produced for two generations. The OPC seeds of 'Kuroda-gosun' were purchased from the Noguchi Seed Co. (Saitama, Japan), and the OPC seeds of 'Chikumano-gosun' were purchased from the International Nature Farming Research Center (Nagano, Japan). The hybrid seed cultivar was 'Kouyounigou', and it was purchased from Takii \& Co. (Kyoto, Japan) (Table 3).

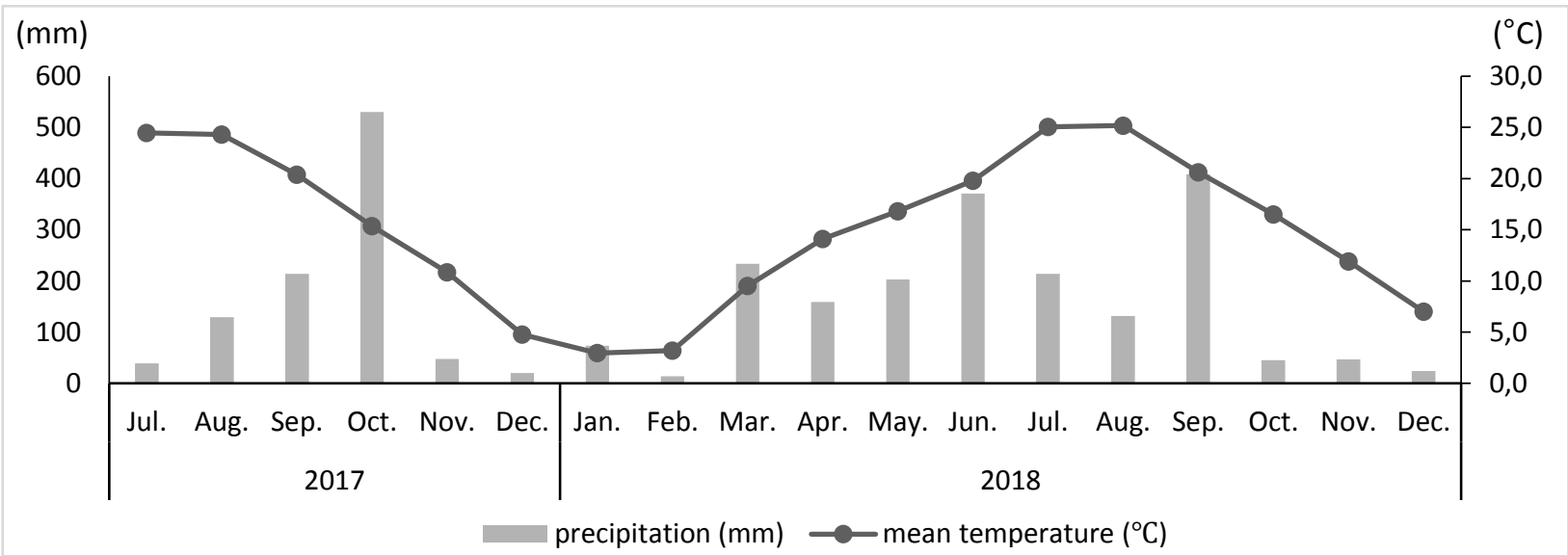

Fig. 1. Daily temperature and precipitation during the three growing seasons (data from the Institute for Agriculture, Medicine, and the Environment)

Table 1. Soil properties of the field

\begin{tabular}{|c|c|c|c|c|c|c|c|c|c|c|}
\hline \multirow[t]{2}{*}{$\mathrm{pH}$} & \multirow{2}{*}{$\begin{array}{c}\text { Electric } \\
\text { conductivity } \\
\left(\mathrm{mS} \cdot \mathrm{cm}^{-1}\right)\end{array}$} & \multirow{2}{*}{$\begin{array}{l}\text { Cation } \\
\text { exchange } \\
\text { capacity } \\
\left(\mathrm{cmolc} \cdot \mathrm{kg}^{-1}\right)\end{array}$} & \multirow{2}{*}{$\begin{array}{c}\text { Total C } \\
(\%)\end{array}$} & \multirow{2}{*}{$\begin{array}{c}\text { Total N } \\
(\%)\end{array}$} & \multirow[t]{2}{*}{$\mathrm{C} / \mathrm{N}$} & \multirow{2}{*}{$\begin{array}{c}\text { Phosphate } \\
\text { absorption } \\
\text { coefficient } \\
\left(\mathrm{g} \cdot \mathrm{kg}^{-1}\right)\end{array}$} & \multirow{2}{*}{$\begin{array}{c}\text { Available } \\
\text { phosphate } \\
\left(\mathrm{mg} \cdot \mathrm{kg}^{-1}\right)\end{array}$} & \multicolumn{3}{|c|}{$\begin{array}{c}\text { Exchangeable cations } \\
\left(\mathrm{g} \cdot \mathrm{kg}^{-1}\right)\end{array}$} \\
\hline & & & & & & & & $\mathrm{K}_{2} \mathrm{O}$ & $\mathrm{CaO}$ & $\mathrm{MgO}$ \\
\hline 6.22 & 0.032 & 27.0 & 2.78 & 0.34 & 8.1 & 20.7 & 6.6 & 0.77 & 1.33 & 0.40 \\
\hline
\end{tabular}

Table 2. Fertilizer input under CF treatment

\begin{tabular}{lcccccc}
\hline \multirow{2}{*}{ Type of fertilizer } & \multicolumn{3}{c}{ Application date } & \multicolumn{3}{c}{ Components (kg ha $\left.^{-1}\right)$} \\
\cline { 2 - 7 } & 2017 & 2018 & 2018 & $\mathrm{~N}$ & $\mathrm{P}_{2} \mathrm{O}_{5}$ & $\mathrm{~K}_{2} \mathrm{O}$ \\
\hline Compound fertilizer (CDU555) & July 11 & Feb. 28 & July 11 & 40 & 40 & 40 \\
\hline Magnesium multi-phosphate (Kudo-Jyusho-Rin) & July 11 & Feb. 28 & July 11 & 0 & 40 & 0 \\
\hline Compound fertilizer (NH-Kasei-2) & Sept. 8 & May 10 & Sept. 12 & 40 & 0 & 40 \\
\hline
\end{tabular}

Table 3. Names of the cultivar and seed supply

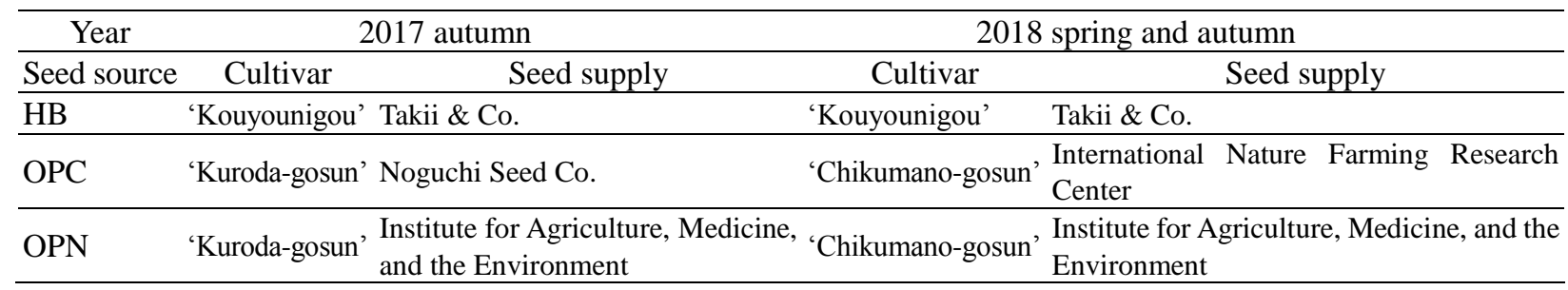




\section{Carrot cultivation}

The soil was tilled to a depth of $0.15 \mathrm{~m}$ before sowing carrot seed in the CT, CF, and NF1 plots. In the NF2 plots, the soil was left undisturbed, apart from scraping the soil surface to remove weeds before sowing. The seeds were sown manually, using a dibbling method, in two lines per ridge with $0.6 \mathrm{~m}$ between rows. Six seeds were sown per hill at $6-\mathrm{cm}$ intervals. In autumn 2017, under NF2, seeds were strip seeded in two lines per ridge, with an interval of approximately $5 \mathrm{~mm}$ between seeds. The number of seeds sown under NF2 in autumn 2017 was estimated using the weight of the seed sown and the average weight of OPC. After thinning, the plant density was 36 plants per $\mathrm{m}^{2}$. Sowing, thinning, and data collection were carried out on the same dates for all treatments (Table 4). No pesticides or herbicides were applied during the experiment. Weeds were removed manually in $\mathrm{CT}, \mathrm{CF}$, and $\mathrm{NF} 1$ and were left as mulch in NF2.

\section{Sampling procedure}

Germination was monitored after sowing, and the germinated seedlings were counted when approximately half of the seeds had germinated in a plot; this was at 21, 10, and 7 days after sowing in autumn 2017, spring 2018, and autumn 2018, respectively. Leaf length was monitored as an index of plant growth. The longest leaf of each plant was measured on 36 plants per plot three times at 2-week intervals. Final sampling was performed using the same 36 plants per plot. The carrots were harvested and separated into leaf and root components. Measurements noted were root weight, root length, maximum root diameter, and leaf weight, and the number of leaves was also recorded. The $\mathrm{R}: \mathrm{S}$ ratio was also calculated from the root and shoot fresh weights.

\section{Statistical analysis}

Analysis of variance (ANOVA) was performed on all the data using $\mathrm{R}$ (Microsoft $\mathrm{R}$ Open 4.0.2 for Windows from Microsoft Corporation) with a splitplot function of the "agricolae" package (version 1.3-3). Logit transformation was performed for the germination data, and $\log$ transformation was performed for other data when required to ensure normal distribution. When significant differences were found among treatments, multiple comparisons were performed using the Bonferroni method.

\section{Germination rate}

\section{RESULTS}

In autumn 2017, the effects of cultivation method and seed source on the germination rate and their interaction were determined (Table 5). The interaction effect indicated that the effect of seed was not consistent across the four cultivation methods. The germination rate for OPN was higher than the rates for $\mathrm{HB}$ and OPC only under NF2, while no such trend was observed under CT, CF, and NF1 (Table 6). In spring and autumn 2018, only a seed source effect was detected (Table 5). The germination rate for OPN was higher than the rates for OPC and HB in spring 2018, and the rates for OPN and OPC were higher than that for HB in autumn 2018.

\section{Leaf length}

The leaf length, which was measured as an index of plant growth, differed significantly among the cultivation methods throughout the growing season but not among the seed sources in autumn 2017 (Table 7). In general, the leaves were significantly longer for CF and NF1 than the ones under NF2. In spring and autumn 2018, in addition to the effect of cultivation methods, an effect of seed source was detected. In the final growth survey, the leaves of plants from OPN and OPC seeds were significantly longer than that for HB seeds in spring 2018, and the leaf length for plants from OPC seeds was significantly more than that for plants from HB seeds in autumn 2018.

\section{Yield parameters}

Among the parameters measured at harvest, seed source effect was determined for root fresh weight, root length, and root maximum diameter in autumn 2017 (Table 8). These values were higher for HB seeds than OPC seeds, while no significant difference was found between HB and OPN seeds. On the other hand, in autumn 2018, the root maximum diameter of OPN was lower than that of HB. Except for these trends, all parameters reflected the trend found for plant leaf length during the growth period (Tables 8 and 9). There were significant differences in $\mathrm{R}: \mathrm{S}$ among the cultivation methods in spring 2018 and among the seed sources in both spring and autumn 2018 (Table 9). When comparing this ratio among the cultivation methods, the values under $\mathrm{CF}$ and NF1 were higher than those under NF2 in spring 2018. Among the seed sources, the values for OPN and OPC seeds were lower than those for HB seeds in both spring and autumn 2018. 
Table 4. Cultivation and sampling schedule

\begin{tabular}{llll}
\hline & 2017 autumn & 2018 spring & 2018 autumn \\
\hline Sowing date & July 26-27 & Mar. 16-17 & July 20-21 \\
\hline Germination survey date & Aug. 16 & Mar. 27 & July 27 \\
\hline \multirow{3}{*}{ Thinning date } & 1st Sept. 1 & 1st Apr. 30 & 1st Aug. 28 \\
& 2nd Sept. 27 & 2nd May 10 & 2nd Sept. 23 \\
& 3rd Oct. 10 & 3rd May 25 & 3rd Oct. 6 \\
Growth survey date & 1st Sept. 29 & 1st May 29 & 1st Sept. 23 \\
& 2nd Oct. 13 & 2nd June 11 & 2nd Oct. 7 \\
\hline Yield survey date & 3rd Oct. 27 & 3rd June 25 & 3rd Oct. 21 \\
\hline
\end{tabular}

Table 5. Effects of cultivation methods and seed sources on germination rate (\%)

\begin{tabular}{lccc}
\hline Treatment & 2017 autumn & 2017 spring & 2018 autumn \\
\hline Method (M) & & & \\
\hline CT & $42.65 \pm 14.47 \mathrm{a}$ & $14.30 \pm 12.39 \mathrm{a}$ & $29.20 \pm 20.68 \mathrm{a}$ \\
CF & $36.59 \pm 12.69 \mathrm{a}$ & $20.85 \pm 22.61 \mathrm{a}$ & $44.76 \pm 32.21 \mathrm{a}$ \\
NF1 & $34.09 \pm 8.09 \mathrm{a}$ & $20.59 \pm 20.46 \mathrm{a}$ & $32.61 \pm 26.93 \mathrm{a}$ \\
NF2 & $3.37 \pm 5.18 \mathrm{~b}$ & $11.65 \pm 13.14 \mathrm{a}$ & $27.40 \pm 19.41 \mathrm{a}$ \\
\hline Significance & $* * *$ & $\mathrm{~ns}$ & $\mathrm{~ns}$ \\
\hline Seed source $(\mathrm{S})$ & & & $3.38 \pm 0.36 \mathrm{c}$ \\
\hline HB & $29.97 \pm 23.37 \mathrm{~b}$ & $15.55 \pm 8.36 \mathrm{~b}$ & $44.06 \pm 15.80 \mathrm{a}$ \\
OPC & $26.17 \pm 17.73 \mathrm{~b}$ & $34.62 \pm 15.91 \mathrm{a}$ & $52.45 \pm 16.72 \mathrm{a}$ \\
OPN & $31.39 \pm 14.78 \mathrm{a}$ & $* * *$ & $* * *$ \\
\hline Significance & $* * *$ & $\mathrm{~ns}$ & $\mathrm{~ns}$ \\
\hline $\mathrm{M} \times$ S interactions & $* * *$ & & \\
\hline
\end{tabular}

The values are the average \pm standard deviation. Means followed by the same letter do not differ significantly according to Bonferroni procedure at $\mathrm{p}=0.05$. ns - not significant, $* \mathrm{p}<0.05, * * \mathrm{p}<0.01, * * * \mathrm{p}<0.001$

$\mathrm{CT}$ - control; $\mathrm{CF}$ - chemical fertilizer; NF1 - natural farming with tillage and compost input; NF2 - natural farming without tillage and compost

Table 6. Effects of cultivation methods and seed sources on germination rate (\%) in autumn 2017

\begin{tabular}{|c|c|c|c|c|}
\hline & \multicolumn{4}{|c|}{ Method (M) } \\
\hline & $\mathrm{CT}$ & $\mathrm{CF}$ & NF1 & NF2 \\
\hline \multicolumn{5}{|c|}{ Seed source $(\mathrm{S})$} \\
\hline $\mathrm{HB}$ & $48.78 \pm 22.84 a$ & $39.11 \pm 20.51 \mathrm{a}$ & $30.94 \pm 12.13 \mathrm{a}$ & $1.05 \pm 1.55 \mathrm{~b}$ \\
\hline $\mathrm{OPC}$ & $37.72 \pm 14.52 \mathrm{a}$ & $34.44 \pm 11.72 \mathrm{a}$ & $32.39 \pm 0.98 \mathrm{a}$ & $0.11 \pm 0.09 \mathrm{~b}$ \\
\hline OPN & $41.44 \pm 3.26 a$ & $36.22 \pm 8.32 \mathrm{a}$ & $38.94 \pm 7.71 \mathrm{a}$ & $8.94 \pm 5.86 \mathrm{a}$ \\
\hline
\end{tabular}

Note: See Table 5 
Table 7. Effects of cultivation methods and seed sources on leaf length during the growth period

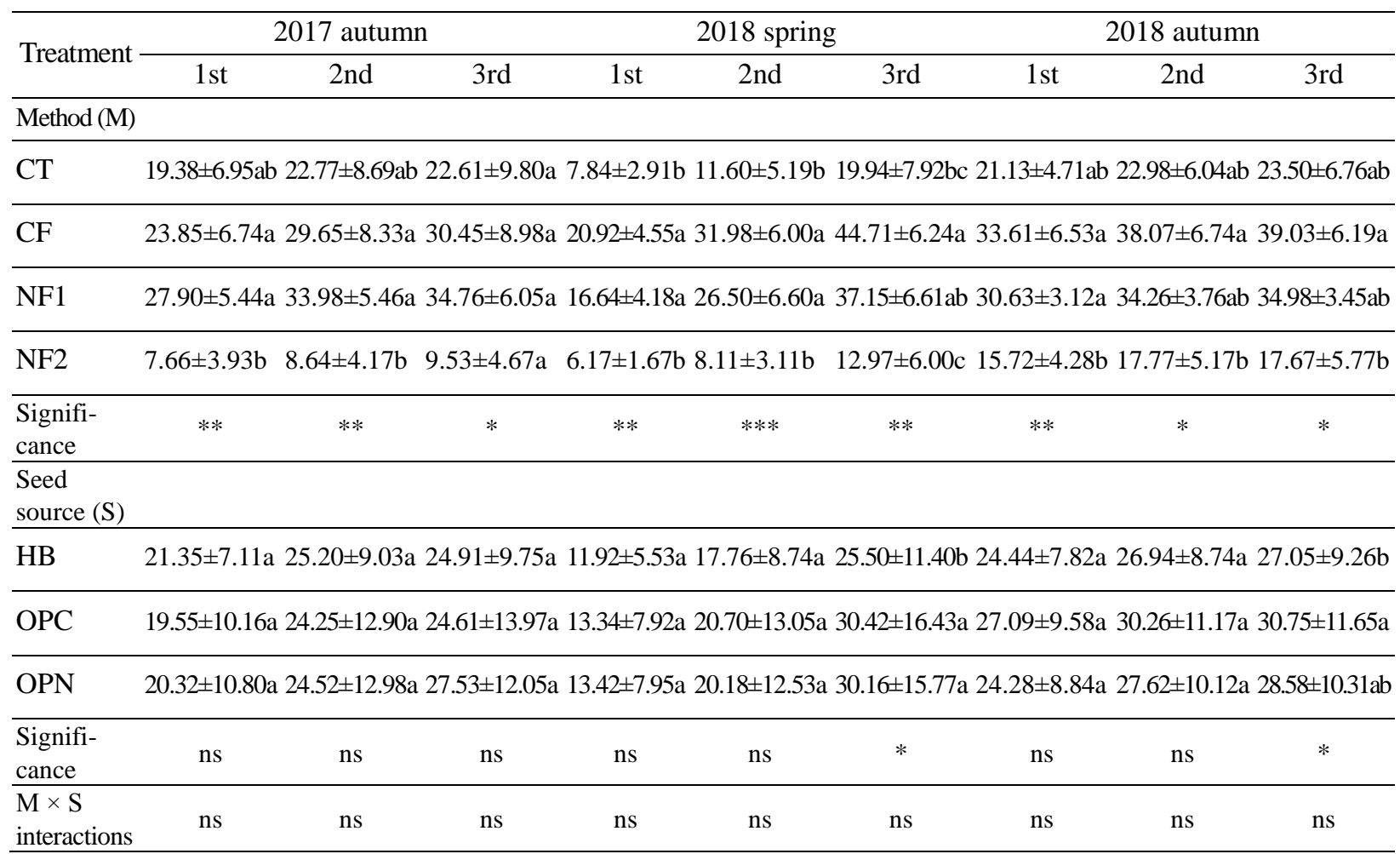

Note: See Table 5

Table 8. Effects of cultivation methods and seed sources on belowground parameters including root fresh weight, root length, and root maximum diameter

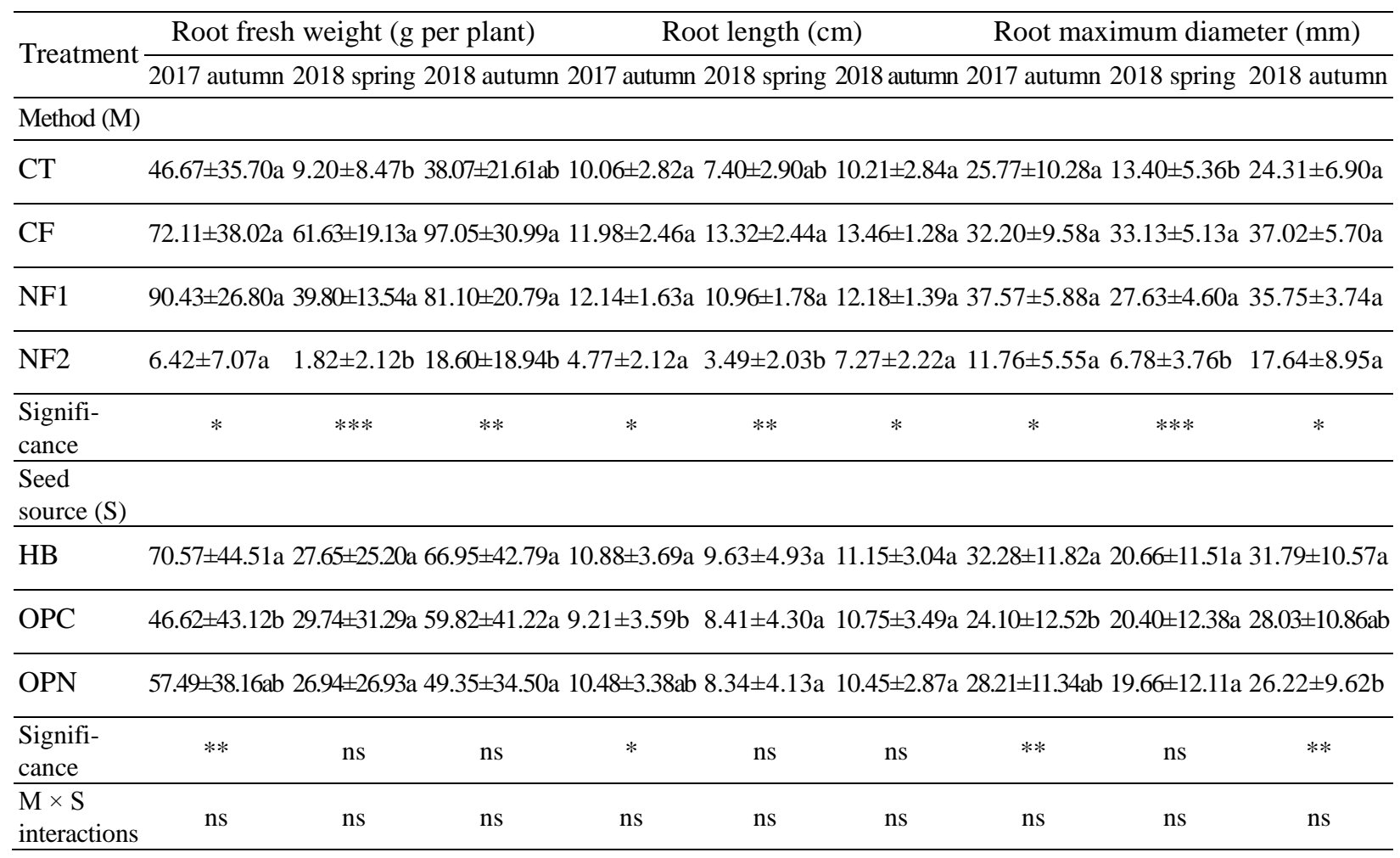

Note: See Table 5 
Table 9. Effects of cultivation methods and seed sources on aboveground parameters including leaf fresh weight, leaf count, and $\mathrm{R}: \mathrm{S}$

\begin{tabular}{|c|c|c|c|c|c|c|c|c|}
\hline \multirow{2}{*}{ Treatment } & \multicolumn{3}{|c|}{ Leaf fresh weight (g per plant) } & \multicolumn{3}{|c|}{ Leaf count } & \multicolumn{2}{|c|}{$\mathrm{R}: \mathrm{S}$ ratio $\left(\mathrm{g} \cdot \mathrm{g}^{-1}\right)$} \\
\hline & 2017 autumn & 2018 spring & 2018 autumn & 2017 autumn & 2018 spring & 2018 autumn & 2017 autumn & 2018 spring 2018 autumn \\
\hline \multicolumn{9}{|l|}{ Method (M) } \\
\hline $\mathrm{CT}$ & - & $7.48 \pm 5.42 \mathrm{bc}$ & $10.10 \pm 6.81 \mathrm{a}$ & $7.31 \pm 1.21 \mathrm{a}$ & $6.70 \pm 1.44 b c$ & $5.24 \pm 1.37 \mathrm{a}$ & - & $1.12 \pm 0.60 \mathrm{ab} \quad 4.18 \pm 1.86 \mathrm{a}$ \\
\hline $\mathrm{CF}$ & - & $48.60 \pm 22.60 \mathrm{a}$ & $28.83 \pm 12.41 \mathrm{a}$ & $7.92 \pm 0.84 \mathrm{a}$ & $9.43 \pm 1.20 \mathrm{a}$ & $6.48 \pm 0.94 \mathrm{a}$ & - & $1.43 \pm 0.61 \mathrm{a} \quad 3.72 \pm 1.67 \mathrm{a}$ \\
\hline NF1 & - & $27.02 \pm 12.22 \mathrm{ab}$ & $21.11 \pm 9.68 \mathrm{a}$ & $7.98 \pm 0.54 \mathrm{a}$ & $8.29 \pm 1.12 \mathrm{ab}$ & $6.02 \pm 1.04 \mathrm{a}$ & - & $1.59 \pm 0.50 \mathrm{a} \quad 4.38 \pm 1.88 \mathrm{a}$ \\
\hline $\mathrm{NF} 2$ & - & $2.45 \pm 2.53 \mathrm{c}$ & $5.64 \pm 4.12 \mathrm{a}$ & $5.66 \pm 1.18 \mathrm{a}$ & $5.00 \pm 0.92 \mathrm{c}$ & $5.35 \pm 0.67 \mathrm{a}$ & - & $0.61 \pm 0.32 \mathrm{~b} \quad 2.79 \pm 1.57 \mathrm{a}$ \\
\hline Significance & - & $* *$ & $*$ & $\mathrm{~ns}$ & $* *$ & $\mathrm{~ns}$ & - & ns \\
\hline \multicolumn{9}{|l|}{$\begin{array}{l}\text { Seed } \\
\text { source }(\mathrm{S})\end{array}$} \\
\hline $\mathrm{HB}$ & - & $12.84 \pm 10.94 b$ & $10.97 \pm 6.84 b$ & $7.03 \pm 1.20 \mathrm{a}$ & $6.69 \pm 1.57 b$ & $5.02 \pm 0.70 \mathrm{~b}$ & - & $1.74 \pm 0.69 \mathrm{a} \quad 5.78 \pm 1.58 \mathrm{a}$ \\
\hline $\mathrm{OPC}$ & - & $25.79 \pm 27.56 \mathrm{a}$ & $20.44 \pm 15.40 \mathrm{a}$ & $7.26 \pm 1.38 \mathrm{a}$ & $7.29 \pm 2.31 \mathrm{ab}$ & $6.09 \pm 1.27 \mathrm{a}$ & - & $0.96 \pm 0.36 \mathrm{~b} \quad 2.84 \pm 0.74 \mathrm{~b}$ \\
\hline OPN & - & $25.54 \pm 24.31 \mathrm{a}$ & $17.85 \pm 12.72 \mathrm{a}$ & $7.80 \pm 1.16 \mathrm{a}$ & $8.08 \pm 2.08 \mathrm{a}$ & $6.21 \pm 0.95 \mathrm{a}$ & - & $0.86 \pm 0.36 b \quad 2.69 \pm 0.69 b$ \\
\hline Significance & - & $* *$ & $* *$ & ns & $* *$ & $* *$ & - & $* * *$ \\
\hline $\begin{array}{l}\mathrm{M} \times \mathrm{S} \\
\text { interactions }\end{array}$ & - & ns & ns & ns & ns & ns & - & ns \\
\hline
\end{tabular}

Note: See Table 5

- no data; $\mathrm{R}: \mathrm{S}$ - root-to-shoot ratio

\section{DISCUSSION}

Self-produced seeds showed positive effects under natural farming conditions in improving crop performance compared to other seeds. In autumn 2017 , the germination rate of OPN seeds was higher than that of other seeds under the NF2 regime. NF2 did not involve tillage, so the soil temperature was likely lower than that with other methods using tillage. The temperature of the soil, when covered with grass mulch without plowing, can be up to $5{ }^{\circ} \mathrm{C}$ lower than that under conventional farming (Jelonkiewicz $\&$ Borowy 2009). As OPN was self-produced under the natural farming system method, the supply of nutrients in the maternal environment was generally low. Luzuriaga et al. (2006) showed that when the maternal environment was nutrient-rich, the germination rate was slow. Although further tests are required to verify our findings, nutrient conditions may have affected the seed germination rate, making the OPN seeds germinate well even at lower temperatures.
The higher germination of OPN compared to HB and OPC seeds in spring 2018 was also in line with this phenomenon. The average temperature during the germination period in spring 2018 was $8.5^{\circ} \mathrm{C}$, which was below the optimum temperature $\left(15-25^{\circ} \mathrm{C}\right)$ for carrot germination (Corbineau et al. 1994; Rubatzky et al. 1999). The higher germination rate at low temperatures may result in a longer growth period, which is often necessary to obtain sufficient yield under natural farming (Takahashi 2010).

Similar to the results of germination rate, the results for root fresh weight also indicated the potential superiority of self-produced seeds. In autumn 2017, root fresh weight and other root parameters of OPC were significantly lower than for HB seeds, as expected, since hybrid seeds generally have higher yield than open-pollinated seeds due to heterosis (Golmirzaie et al. 1998). On the other hand, the root parameters for OPN were as high as for HB seeds, suggesting that the self-produced seeds may enable farmers to obtain open-pollinated seeds that have 
a yield potential similar to that of hybrid seeds. However, in spring and autumn 2018, no such differences were found, and the values for OPN were actually the lowest among the three seed sources. This discrepancy among different cultivation seasons could be due to the difference in years invested in seed self-production. The seed type used for OPN in autumn 2017 was 'Kuroda-gosun', which had been self-produced for more than 10 generations. On the other hand, the seed type used in spring and autumn 2018 was 'Chikumano-gosun', which had been self-produced for only two generations. The possibility of different genotype responses to natural growing conditions should also be taken into account. In contrast to the previous study that showed changes in the $\mathrm{R}: \mathrm{S}$ ratio with the maternal nutrient conditions (Verhoeven \& van Gurp 2012), no R : S differences between OPN and OPC seeds were detected, and the only difference detected was between HB seeds and others. Since the difference in $\mathrm{R}$ : $\mathrm{S}$ ratio among the contrasting cultivars is similar across the environmental gradient (Xu et al. 2018), the difference between cultivars in our study may have masked any responses to the maternal environment for R : $\mathrm{S}$ in open-pollinated seeds. It was difficult to detect the difference between means on seed sources compared to cultivation methods because the alpha levels are adjusted for the multiple comparisons. Furthermore, the R:S ratio under NF2 was lower than that under CT and NF1 in this study, probably due to the increased soil strength under notillage, which in turn inhibits root growth (Howeler et al. 1993).

Compared to other cultivation methods, the yield of NF2 was much lower. This is not surprising, considering that this is only the result of the first or second year. One of the well-known leaders of this farming method stated that it took 10 years to get a reasonable yield because it takes time for the soil to become suitable (Kawaguchi \& Tsuji 2011). In Japan, the main soils, called andosols, can fix large amounts of organic matter (Sawanobori \& Komatsuzaki 2019). In the field experiments conducted in Japanese soils, soil organic carbon has been shown to increase when cover crop residues and weed residues are combined with notill systems (Arai et al. 2014; Higashi et al. 2014).
A meta-analysis of the relationship between soil carbon and crop yield has shown that crop yield increases with increasing carbon concentration (Oldfield et al. 2019). In addition to increasing carbon concentration, no-till systems also contribute to the diversity of soil microbiology and animal communities (Komatsuzaki \& Ohta 2007; Kaneko et al. 2018; Sawanobori \& Komatsuzaki 2019). Filser et al. (2016) found that soil microbiological and animal activity has direct and indirect effects on carbon sequestration and nutrient supply. No-till cultivation represented relatively lower yields in the first 1-2 years, but after $4-5$ years the yields were comparable, and after 6 years the yields were higher in no-till cultivation (Pittelkow et al. 2015). Hence, it is expected that in NF2, crop yields will gradually increase with increasing carbon concentration over time, although yields will decrease initially.

Natural farming is not an established field of research, but it is the one that should be expanded in the future. In fact, to the best of our knowledge, there are no previous studies similar to the present study at this time. A long-term trial with NF2 may reveal the effects of seed self-production.

\section{CONCLUSION}

In this study, the germination rate of selfproduced seeds was higher than that of other seeds. In addition, the root fresh weight and other root parameters of self-produced seeds for more than 10 generations were as high as for hybrid seeds. This suggests that using self-produced seeds by farmers improves crop performance in a natural farming system. Our research results also provided the implication that not only does soil preparation take years, but also seed self-cultivation may be effective only after years of repeated practice. It is necessary to develop technology to shorten the time it takes to secure the yield in a natural farming system.

\section{Acknowledgments}

The authors thank the staff of the Institute for Agriculture, Medicine, and the Environment and the MOA Natural Farming and Culture Foundation for their support in conducting the experiments, and Hiroaki Takahashi for the advice on Sizen-no cultivation. 


\section{REFERENCES}

Arai M., Minamiya Y., Tsuzura H., Watanabe Y., Yagioka A., Kaneko N. 2014. Changes in water stable aggregate and soil carbon accumulation in a no-tillage with weed mulch management site after conversion from conventional management practices. Geoderma $221-$ 222: 50-60. DOI: 10.1016/j.geoderma.2014.01.022.

Balao F., Paun O., Alonso C. 2018. Uncovering the contribution of epigenetics to plant phenotypic variation in Mediterranean ecosystems. Plant Biology 20(Supplement 1): 38-49. DOI: 10.1111/plb.12594.

Boyko A., Kovalchuk I. 2008. Epigenetic control of plant stress response. Environmental and Molecular $\mathrm{Mu}-$ tagenesis 49(1): 61-72. DOI: 10.1002/em.20347.

Bräutigam K., Vining K.J., Lafon-Placette C., Fossdal C.G., Mirouze M., Marcos J.G. et al. 2013. Epigenetic regulation of adaptive responses of forest tree species to the environment. Ecology and Evolution 3(2): 339-415. DOI: 10.1002/ece3.461.

Corbineau F., Picard M.A., Côme D. 1994. Effects of temperature, oxygen and osmotic pressure on germination of carrot seeds: Evaluation of seed quality. Acta Horticulturae 354: 9-16. DOI: 10.17660/actahortic.1994.354.1.

Filser J., Faber J.H., Tiunov A.V., Brussaard L., Frouz J., De Deyn G. et al. 2016. Soil fauna: key to new carbon models. Soil 2(4): 565-582. DOI: 10.5194/soil-2016-19.

Fukasawa T. 2020. UN Decade of Family Farming, UN Declaration on the Rights of Peasants, and the Promotion of the Subsistence Farming on a Small Scale. Yamanashi Gakuin University. Journal of Management Studies 1(3): 45-61. [in Japanese]

Fukuda K. 2018. The advantage of natural farming as an eco-friendly way of living: practice and discourse on the "learners' fields" in Fukuoka, Japan. Culture, Agriculture, Food and Environment 40(1): 15-23. DOI: 10.1111/cuag.12101.

Fukuoka M. 2004. Shizen Nōhō: Wara ippon no kakumei. Natural Farming: The One-Straw Revolution, 2nd ed. Shunjūsha, Tokyo, Japan. [in Japanese]

Golmirzaie A.M., Ortiz R., Atlin G.N., Iwanaga M. 1998. Inbreeding and true seed in tetrasomic potato. I. Selfing and open pollination in Andean landraces (Solanum tuberosum Gp. Andigena). Theoretical and Applied Genetics 97(7): 1125-1128. DOI: 10.1007/s001220051000.

Higashi T., Mu Y., Komatsuzaki M., Miura S., Hirata T., Araki H. et al. 2014. Tillage and cover crop species affect soil organic carbon in Andosol, Kanto, Japan. Soil and Tillage Research 138: 64-72. DOI: 10.1016/j.still.2013.12.010.
Howeler R.H., Ezumah H.C., Midmore D.J. 1993. Tillage systems for root and tuber crops in the tropics. Soil and Tillage Research 27(1-4): 211-240. DOI: 10.1016/0167-1987(93)90069-2.

Jelonkiewicz M., Borowy A. 2009. Growth and yield of cucumber under no-tillage cultivation using rye as a cover crop. Acta Agrobotanica 62(1): 147-153. DOI: $10.5586 /$ aa.2009.017.

Kaneko N., Inoue K., Minamiya Y., Miura T., Tsunoda T., Ikeda H., Sugiyama S. 2018. Soil biodiversity of organic apple orchard: comparison with conventional orchard and forest. Edaphologia 102: 31-39. DOI: 10.20695/edaphologia.102.0_31. [in Japanese with English abstract]

Komatsuzaki M., Ohta H. 2007. Soil management practices for sustainable agro-ecosystems. Sustainability Science 2: 103-120. DOI: 10.1007/s11625-006-0014-5.

Kawaguchi, K., Nakamoto E., Hu B. 2014. An empirical examination to natural farming: theory and practice. Memoirs of the College of Agriculture, Ehime University 59: 1-8. [in Japanese]

Kawaguchi Y., Tsuji S. 2011. Shizennō to iu Ikikata. Natural Farming: A Way of Life. Ōtsukishoten, Tokyo, Japan. [in Japanese]

Kutka F. 2011. Open-pollinated vs. hybrid maize cultivars. Sustainability 3(9): 1531-1554. DOI: 10.3390/su3091531.

Luzuriaga A.L., Escudero A., Pérez-García F. 2006. Environmental maternal effects on seed morphology and germination in Sinapis arvensis (Cruciferae). Weed Research 46(2): 163-174. DOI: 10.1111/j.1365-3180.2006.00496.x.

Macharia C.N., Njeru C.M., Ombakho G.A., Shiluli M.S. 2010. Comparative performance of advanced generations of maize hybrids with a local maize variety: agronomic and financial implications for smallholder farmers. Journal of Animal \& Plant Sciences 7(2): 801-809.

MAFF 2017. Kokuren 'Kazoku nōgyō no 10 nen (20192028). Ministry of Agriculture, Forestry and Fisheries, Japan. https://www.maff.go.jp/j/kokusai/kokusei/kanren_sesaku/FAO/undecade_family_farming.html (accessed April 28, 2021) [in Japanese]

MAFF 2019. Current situation and policy on organic agriculture in Japan. Ministry of Agriculture, Forestry and Fisheries, Japan. https://www.maff.go.jp/e/policies/env/sustainagri/attach/pdf/organicagri-1.pdf (accessed April 28, 2021)

Mitra P., Kaneko N., Watanabe Y. 2017. Methane emission from no-tillage with weed green mulch paddy field. Japanese Journal of Organic Agriculture Science 9(2): 48-52. DOI: 10.24757/joas.9.2_48. [in Japanese with English abstract] 
Oldfield E.E., Bradford M.A., Wood S.A. 2019. Global meta-analysis of the relationship between soil organic matter and crop yields. Soil 5: 15-32. DOI: 10.5194/soil-5-15-2019.

Omondi E.C., Norton J.B., Ashilenje D.S. 2014. Performance of a local open pollinated maize variety and a common hybrid variety under intensive small-scale farming practices. African Journal of Agricultural Research 9(11): 950-955. DOI: 10.5897/ajar2013.7359.

Pittelkow C.M., Linquist B.A., Lundy M.E., Liang X., van Groenigen K.J., Lee J. et al. 2015. When does no-till yield more? A global meta-analysis. Field Crops Research 183: 156-168. DOI: 10.1016/j.fcr.2015.07.020.

Rubatzky V.E., Quiros C.F., Simon P.W. 1999. Carrots and related vegetable Umbelliferae. Crop Production Science in Horticulture 10. CABI, United Kingdom, 294 p.

Sawanobori S., Komatsuzaki M. 2019. Yūkinōgyō taizen. The complete book of Japanese organic agriculture: sustainable farming practices and philosophy, 1st ed. Commons, Tokyo, Japan. [in Japanese]
Tabuchi H., Kato K., Nioh I. 2008. Season and soil management affect soil microbial communities estimated using phospholipid fatty acid analysis in a continuous cabbage (Brassica oleracea var. capitata) cropping system. Soil Science and Plant Nutrition 54(3): 369-378. DOI: 10.1111/j.1747-0765.2008.00242.x.

Takahashi H. 2010. Shizennō no Yasai Tsukuri. Soshinsha, Tokyo, Japan. [in Japanese]

Verhoeven K.J.F., van Gurp T.P. 2012. Transgenerational effects of stress exposure on offspring phenotypes in apomictic dandelion. PLoS ONE 7(6); e38605; 8 p. DOI: 10.1371/journal.pone.0038605.

Xu Z.-M., Mei X.-Q., Tan L., Li Q.-S., Wang L.-L., He B.-Y. et al. 2018. Low root/shoot (R/S) biomass ratio can be an indicator of low cadmium accumulation in the shoot of Chinese flowering cabbage (Brassica campestris L. ssp. chinensis var. utilis Tsen et Lee) cultivars. Environmental Science and Pollution Research 25(36): 36328-36340. DOI: 10.1007/s11356-018-3566-x. 